\title{
Environmental chemistry is most relevant to study coronavirus pandemics
}

\author{
Virender K. Sharma ${ }^{1}$. Chetan Jinadatha ${ }^{2}$. Eric Lichtfouse ${ }^{3}(\mathbb{C}$
}

Published online: 20 May 2020

C) Springer Nature Switzerland AG 2020

On May 18, 2020, the COVID-19 pandemic has globally killed 315,248 people since the virus outbreak in Wuhan, China, in early December 2019 (https://gisanddata.maps. arcgis.com/apps/opsdashboard/index.html\#/bda7594740 fd40299423467b48e9ecf6). As a matter of urgency, research has promptly focused on designing cures and vaccines, which is understandable, but is the classical 'painkiller' approach that will be less and less efficient in our globalized society because such an approach is treating the effect and not the original cause (Lichtfouse 2009, 2010). In particular, this is somehow underestimating environmental factors such as climate change and pollution that have more or less directly favored the pandemic. For instance, climate modeling has predicted increased risks of food- and waterborne diseases with very high confidence (Woodward et al. 2014). Similarly, air pollution has been shown to alter the immune system (Glencross et al. 2020; Bauer et al. 2012). Environmental chemistry, as the science of contaminants in the environment, thus deserves more attention to prevent future pandemics (Qu et al. 2020).

The emergence of viral epidemics in the past 20 years has caused great threats to public health (Wang et al. 2020). Lassa and Ebola are examples of infectious viruses associated with hemorrhagic fever. The novel coronavirus is

Virender K. Sharma

vsharma@tamu.edu

Chetan Jinadatha

chetan.jinadatha@va.gov

Eric Lichtfouse

eric.lichtfouse@gmail.com

1 Department of Environmental and Occupational Health, School of Public Health, Texas A\&M University, College Station, TX 77843, USA

2 Central Texas Veterans Health Care System, 1901 Veterans Memorial Drive, Temple, TX, USA

3 CNRS, IRD, INRAE, Coll France, CEREGE, Aix-Marseille Univ, 13100 Aix-en-Provence, France a class of enveloped, positive-sense single-stranded RNA viruses that are responsible for the Middle East respiratory syndrome, MERS-CoV, and the severe acute respiratory syndrome, SARS-CoV, in humans. The current pandemic caused by the novel coronavirus SARS-CoV-2 causes severe acute respiratory symptoms and is often referred to as coronavirus infectious diseases 2019: COVID-19. No effective vaccine or drugs are available, which makes it very challenging to treat or prevent the deadly COVID-19. Below are some of our thoughts on how environmental chemists can play pivotal role in understanding the occurrence and evolution of COVID-19 in protection of the global community.

In the environment, SARS-CoV-2 may survive in the air, on the surfaces, in water and wastewater (Qu et al. 2020). In the air, the SARS-CoV-2 virus may be present as droplets, or as dust, or particulate matter (PM). The decay of the virus under various environmental conditions would determine the survival of the virus. These conditions may include the size of particulate matter and aerosols, humidity and temperature. These suggest the potential role of climate change on occurrence and the fate of the virus. Environmental chemistry research on the fate of pollutants in air (Kfoury et al. 2016; Yu 2019; Gopinath and Kadirvelu 2018), water (Gopinath and Kadirvelu 2018; Mahmood et al. 2012; Rodgers et al. 2019; Wen et al. 2019) and wastewater (Padervand et al. 2020; Simas et al. 2019; Villaseñor and Ríos 2018; Crini and Lichtfouse 2019) is therefore highly relevant to the study of pathogenic microbes. Future detailed investigations about the physiochemical role of environmental parameters of air might therefore address the control of future outbreaks or pandemics with greater efficiency.

The survival of SARS-CoV-2 on solid surfaces might be of high importance. For example, the novel coronavirus may survive for prolonged periods on surfaces such as latex gloves, sterile sponges, aluminum, wood, laminate, steel and plastics. Viruses usually have longer survival in a host and thus may have increased likelihood of transmission. Similarly, complete information is essential on how the novel 
coronavirus interacts with surfaces on a mask that vary in composition, material and pore size to understand survival and protection. Systematically designed experiments will help us gain insight into the virus survival on various surfaces, thus minimizing the exposure of the novel coronavirus to the humans. Here, recent research in environmental chemistry has shown the role of surface materials on antimicrobial resistance (Khan et al. 2019) and bacterial communities (Dong et al. 2019).

Surprisingly, researchers are paying little attention on the interaction of the virus with food products such as vegetable and fruits, whereas food-borne outbreaks such as diarrheal outbreaks due to the contamination of food by Escherichia coli in spinach are well described (Sharapov et al. 2016). Fundamental understanding of the survival and possible replication of SARS-CoV-2 on different food will improve food security and safety of the global community. Additional insights might be gained from recent reports on smart packaging (Rai et al. 2019; Gaikwad et al. 2019; Pandit et al. 2017), biosensors (Brinda et al. 2018; Jyoti and Tomar 2017) and nanotechnology (Manickam et al. 2017; Dasgupta et al. 2019) (Fig. 1).

Generally, viruses in water come from excretion in feces. Viruses can survive in fecal matter and in sewage water for up to 10 days. Very little information is currently available on the transmission of enveloped viruses via feco-oral transmission or through our sewer system. In case of the 2003 SARS outbreak, the human coronavirus was found in stool samples (Peiris et al. 2003). The urine samples have also shown human enveloped viruses such as the cytomegalovirus (CMV).

The first detection of SARS-CoV-2 in sewage occurred on March 5, 2020 in the sewage systems of the Schiphol airoport and major cities in the Netherlands, only one week into the epidemic (Medema et al. 2020). Coronavirus-type viruses may inactivate in wastewater, with temperature highly influencing the inactivation rate (Wigginton and Boehm 2020). During wastewater treatment, oxidants and disinfectants can inactivate enveloped viruses (Manoli et al. 2020). However, many poor communities lack the infrastructure to provide clean water, and therefore would face exposure of infectious viruses. Additionally, faulty plumbing in buildings may increase exposure to the viruses. Very limited data sets are available on human viruses in the literature. Research on enveloped-virus transmission and on the treatment of wastewater must include a wide range of enveloped viruses. Here, environmental chemists have developed a wide array of wastewater treatment techniques (Crini and Lichtfouse 2019; Bello and Raman 2019; Crini et al. 2019; Lichtfouse et al. 2019; Bouabidi et al. 2019; Bourgeois et al. 2015), which deserve further testing for virus inactivation.

In determining the fate of novel coronavirus, measurements should be conducted with great care regarding conditions and characterizing the media composition. The purity of the stock of virus must be checked fully. Many efforts should be made to explain the novel coronavirus concentrations in gene copies and infected units. The recommendation of using oxidants and disinfectants to inactivate
Fig. 1 Environmental research findings on nanoparticles could be useful to study the behavior of viruses. Modified after Manickam et al. (2017)

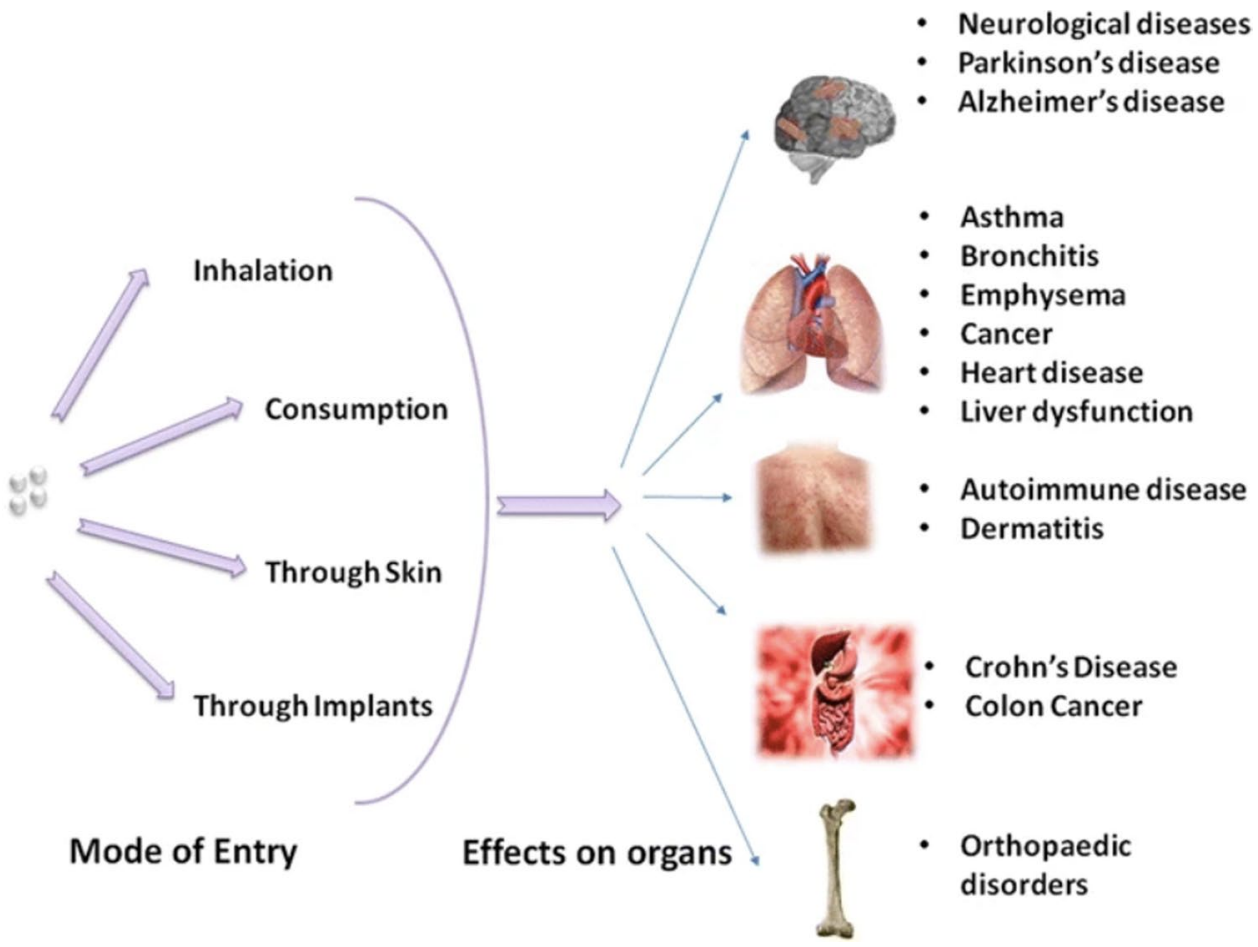


SARS-CoV-2 must be experimentally based, which includes testing dose demand and contact time under the environmental conditions at which the virus would be presented. In applying light-based processes to inactivate the SARS$\mathrm{CoV}-2$, attenuation through the treated water must be fully reported. Researchers should also study the surrogate virus, similarly as the well-investigated nonenveloped bacteriophage MS2, thus enabling different laboratories in world to compare their findings among different global communities.

Overall, research in environmental chemistry is disclosing unique knowledge that may help to understand the behavior of viruses and other microbial pathogens in the environment. Therefore, we advise that environmental chemists and biomedical scientists collaborate to decipher mechanisms and design adapted treatments to fight pandemics.

\section{References}

Bauer RN, Diaz-Sanchez D, Jaspers L (2012) Effects of air pollutants on innate immunity: the role of Toll-like receptors and nucleotidebinding oligomerization domain-like receptors. J Allergy Clin Immunol 129:14-24. https://doi.org/10.1016/j.jaci.2011.11.004

Bello MM, Raman AAA (2019) Synergy of adsorption and advanced oxidation processes in recalcitrant wastewater treatment. Environ Chem Lett 17:1125-1142. https://doi.org/10.1007/s10311-01800842-0

Bouabidi ZB, El-Naas MH, Zhang Z (2019) Immobilization of microbial cells for the biotreatment of wastewater: a review. Environ Chem Lett 17:241-257. https://doi.org/10.1007/s1031 1-018-0795-7

Bourgeois E, Dequiedt S, Lelièvre M, Oort F, Lamy I, Ranjard L, Maron PA (2015) Miscanthus bioenergy crop stimulates nutrientcycler bacteria and fungi in wastewater-contaminated agricultural soil. Environ Chem Lett 13:503-511. https://doi.org/10.1007/ s10311-015-0532-4

Brinda J, Chanda K, Balamurali MM (2018) Biosensors for pathogen surveillance. Environ Chem Lett 16:1325-1337. https://doi. org/10.1007/s10311-018-0759-y

COVID-19 Dashboard by the Center for Systems Science and Engineering at Johns Hopkins University. ArcGIS. Johns Hopkins University. https://gisanddata.maps.arcgis.com/apps/opsdashboa rd/index.html\#/bda7594740fd40299423467b48e9ecf6

Crini G, Lichtfouse E (2019) Advantages and disadvantages of techniques used for wastewater treatment. Environ Chem Lett 17:145155. https://doi.org/10.1007/s10311-018-0785-9

Crini G, Lichtfouse E, Wilson LD, Morin-Crini N (2019) Conventional and non-conventional adsorbents for wastewater treatment. Environ Chem Lett 17:195-213. https://doi.org/10.1007/s1031 1-018-0786-8

Dasgupta N, Ranjan S, Gandhi M (2019) Nanoemulsions in food: market demand. Environ Chem Lett 17:1003-1009. https://doi. org/10.1007/s10311-019-00856-2

Dong F, Li C, Lin Q, Duan H (2019) Effect of pipe materials on disinfection by-products and bacterial communities during sulfamethazine chlorination in a pilot-scale water distribution system. Environ Chem Lett 17:1039-1044. https://doi.org/10.1007/s1031 1-018-00823-3
Gaikwad KK, Singh S, Ajji A (2019) Moisture absorbers for food packaging applications. Environ Chem Lett 17:609-628. https://doi. org/10.1007/s10311-018-0810-z

Glencross DA, Ho TR, Camina N, Hawrylowicz CM, Pfeffer PE (2020) Air pollution and its effects on the immune system. Free Radic Biol Med. https://doi.org/10.1016/j.freeradbiomed.2020.01.179

Gopinath A, Kadirvelu K (2018) Strategies to design modified activated carbon fibers for the decontamination of water and air. Environ Chem Lett 16:1137-1168. https://doi.org/10.1007/s1031 1-018-0740-9

Jyoti A, Tomar RS (2017) Detection of pathogenic bacteria using nanobiosensors. Environ Chem Lett 15:1-6. https://doi.org/10.1007/ s10311-016-0594-y

Kfoury M, Borgie M, Verdin A, Ledoux F, Courcot D, Auezova L, Fourmentin S (2016) Essential oil components decrease pulmonary and hepatic cells inflammation induced by air pollution particulate matter. Environ Chem Lett 14:345-351. https://doi. org/10.1007/s10311-016-0572-4

Khan S, Beattie TK, Knapp CW (2019) Rapid selection of antimicrobial-resistant bacteria in complex water systems by chlorine and pipe materials. Environ Chem Lett 17:1367-1373. https:// doi.org/10.1007/s10311-019-00867-z

Lichtfouse E (2009) Climate change, society issues and sustainable agriculture. In: Climate change, intercropping, pest control and beneficial microorganism; Sustainable Agriculture Reviews, vol 2. Springer, Berlin, pp 1-7. https://doi. org/10.1007/978-90-481-2716-0_1

Lichtfouse E (2010) Society issues, painkiller solutions, dependence and sustainable agriculture. In: Sociology, organic farming, climate change and soil science; Sustainable Agriculture Reviews, vol 3. Springer, Berlin, pp 1-17. https://doi. org/10.1007/978-90-481-3333-8_1

Lichtfouse E, Morin-Crini N, Fourmentin M, Zemmouri H, Nascimento IOC, Queiroz LM, Tadza MY, Picos-Corrales LA, Pei H, Wilson LD, Crini G (2019) Chitosan for direct bioflocculation of wastewater. Environ Chem Lett 17:1603-1621. https://doi. org/10.1007/s10311-019-00900-1

Mahmood MA, Baruah S, Anal AK, Dutta J (2012) Heterogeneous photocatalysis for removal of microbes from water. Environ Chem Lett 10:145-151. https://doi.org/10.1007/s10311-011-0347-x

Manickam V, Velusamy RK, Lochana R, Rajendran B, Tamizhselvi R (2017) Applications and genotoxicity of nanomaterials in the food industry. Environ Chem Lett 15:399-412. https://doi.org/10.1007/ s10311-017-0633-3

Manoli K, Maffettone R, Sharma VK, Santoro D, Ray AK, Passalacqua KD, Carnahan KE, Wobus C, Sarathy S (2020) Inactivation of murine norovirus and fecal coliforms by ferrate(VI) in secondary effluent wastewater. Enviorn Sci Technol 54:1878-1888

Medema G, Heijnen L, Elsinga G, Italiaander R, Anke Brouwer A (2020) Presence of SARS-Coronavirus-2 in sewage. medRxiv 2020.03.29.20045880. https://doi.org/10.1101/2020.03.29.20045 880

Padervand M, Lichtfouse E, Robert D, Wang C (2020) Removal of microplastics from the environment. A review. Environ Chem Lett 18:807-828. https://doi.org/10.1007/s10311-020-00983-1

Pandit R, Rai M, Santos CA (2017) Enhanced antimicrobial activity of the food-protecting nisin peptide by bioconjugation with silver nanoparticles. Environ Chem Lett 15:443-452. https://doi. org/10.1007/s10311-017-0626-2

Peiris JSM, Chu CM, Cheng VCC, Chan KS, Hung IFN, Poon LLM, Law KI, Tang BSF, Hon TYW, Chan CS, Chan KH, Ng JSC, Zheng BJ, Ng WL, Lai RWM, Guan Y, Yuen KY (2003) Clinical progression and viral load in a community outbreak of coronavirus-associated SARS pneumonia: a prospective study. Lancet 361:1767-1772. https://doi.org/10.1016/S0140-6736(03)13412-5 
Qu G, Li X, Hu L, Jiang G (2020) An imperative need for research on the role of environmental factors in transmission of novel coronavirus (COVID-19). Environ Sci Technol. https://doi.org/10.1021/ acs.est.0c01102

Rai M, Ingle AP, Gupta I, Pandit R, Paralikar P, Gade A, Chaud MV, Santos CA (2019) Smart nanopackaging for the enhancement of food shelf life. Environ Chem Lett 17:277-290. https://doi. org/10.1007/s10311-018-0794-8

Rodgers K, McLellan I, Peshkur T, Williams R, Tonner R, Hursthouse AS, Knapp CW, Henriquez FL (2019) Can the legacy of industrial pollution influence antimicrobial resistance in estuarine sediments? Environ Chem Lett 17:595-607. https://doi.org/10.1007/ s10311-018-0791-y

Sharapov UM, Wendel AM, Davis JP, Keene WE, Farrar J, Sodha S, Hyytia-Trees E, Leeper M, Gerner-Smidt P, Griffin PM, Braden C (2016) Multistate outbreak of Escherichia coli O157:H7 infections associated with consumption of fresh spinach: United States, 2006. J Food Protection 79:2024-2030. https://doi. org/10.4315/0362-028X.JFP-15-556

Simas A, Mores R, Steffens J, Dallago RM, Kunz A, Michelon W, Fongaro G, Viancelli A (2019) Electrodisinfection of real swine wastewater for water reuse. Environ Chem Lett 17:495-499. https ://doi.org/10.1007/s10311-018-0782-z

Villaseñor MJ, Ríos Á (2018) Nanomaterials for water cleaning and desalination, energy production, disinfection, agriculture and green chemistry. Environ Chem Lett 16:11-34. https://doi. org/10.1007/s10311-017-0656-9
Wang C, Horby PW, Hayden FG, Gao GF (2020) A novel coronavirus outbreak of global health concern. Lancet 395:470-473. https:// doi.org/10.1016/S0140-6736(20)30185-9

Wen Y, Yuan J, Ma X, Wang S, Liu Y (2019) Polymeric nanocomposite membranes for water treatment: a review. Environ Chem Lett 17:1539-1551. https://doi.org/10.1007/s10311-019-00895-9

Wigginton KR, Boehm AB (2020) Environmental engineers and scientists have important roles to play in stemming outbreaks and pandemics caused by enveloped viruses. Environ Sci Technol. https://doi.org/10.1021/acs.est.0c01476

Woodward A, Smith K, Campbell-Lendrum D, Chadeed DD, Honda Y, Liu Q, Olwoch J, Revich B, Sauerborn R, Chafe Z, Confalonieri U, Hainesk A (2014) Climate change and health: on the latest IPCC report. The Lancet 383:1185-1189. https://doi.org/10.1016/ S0140-6736(14)60576-6

Yu S (2019) Fog geoengineering to abate local ozone pollution at ground level by enhancing air moisture. Environ Chem Lett 17:565-580. https://doi.org/10.1007/s10311-018-0809-5

Publisher's Note Springer Nature remains neutral with regard to jurisdictional claims in published maps and institutional affiliations. 